\title{
不透明体で半透明体を挟んだ二層材の 見かけの定常熱伝導率の検言 \\ Examination of Apparent Steady State Thermal Conductivity of 3-Layer Material with Semitransparent Material Sandwiched by Opaque Layer
}

\author{
細野和也* 西剛史** 太田弘道** \\ Kazuya Hosono, Tsuyoshi Nishi, and Hiromichi Ohta
}

\begin{abstract}
ガラス等の均質, 緻密な半透明体の熱伝導は, 熱伝導だけでなく熱放射を伴う。このような熱伝導 ／熱放射が共存する半透明体の定常状態における見かけの熱伝導率の必要性は高い. ラプラス変換を 用いて, 両端不透明層とした半透明体の一端を一定熱流束で加熱したときの時間無限大における温度 式を求め，これから半透明体の定常温度分布式を導き，この温度分布の光学厚さおよび温度依存性を 検討した．半透明体の定常温度分布より光学厚さ全領域の見かけの熱伝導率式を導き，見かけの熱伝 導率の光学厚さが大きい領域および小さい領域の見かけの熱伝導率近似式を導いた．光学厚さが大き い領域の見かけの熱伝導率近似式はロスランド近似式と同じ傾向を示した.
\end{abstract}

The thermal conduction of homogeneous and dense semitransparent materials like glasses consists of conductive and radiative heat transfer. The apparent thermal conductivity in steady state of semitransparent material where conductive and radiative heat transfer coexist is necessary. After deriving a temperature equation at infinity in Laplace space when steady heating one end of a 3-layer material with semitransparent material sandwiched by opaque layer, the steady-state temperature distribution equation was derived and the optical thickness and temperature dependence of the temperature distribution was investigated. Apparent steady-state thermal conductivity for entire optical thickness was derived from the temperature distribution of semitransparent material. The approximate thermal conductivity equations for large and small optical thickness were derived. The apparent thermal conductivity approximation for large optical thickness showed the same trend as the apparent thermal conductivity by Rosseland.

[Keywords: semitransparent material, diffusive/radiative thermal conduction, steady apparent thermal conductivity, stationary measurement method]

\section{1.はじめに}

均質, 緻密なガラス、セラミックス等の多くは赤外線 の放射と吸収を行うため熱的には半透明体に分類され，そ の熱移動は熱伝導と熱放射の組み合わされたものとなる. このような熱伝導と熱放射が共存する半透明体の熱移動 に関する研究は, 過去に多くなされている 11$]-[14]$ 。この うち断熱材定常熱伝導に関する研究 [10]-[12]は，その熱 伝導率を熱伝導, 熱放射, 対流によるものの和として取り 扱っている．また，熱放射が存在する場合にロスランドの

*(株超高温材料研究センター， 干755-0001 宇部市大字沖宇部 573 番地-3. FAX: 0836-51-7165 E-mail:hosono@jutem.co.jp

** 茨城大学大学院理工学研究科量子線科学専攻, †316-8511

日立市中成沢町 4-12-1. Graduate School of Science and Engineering, Ibaraki University, 4-12-1 Nakanarusawa-cho, Ibaraki, 316-8511.
近似式 $[3]$ が多く使用されるが，同式は吸収係数がある程 度以上大きい領域に対してのみ成立するため, この条件を 満たさない場合には適用できない, 一方, 吸収係数が小さ く吸収係数と厚さの積である光学厚さが 0.1 より小さい 場合には材料内の吸収・放射現象が無視できることが文献 [4]で示され，文献[5][9]においてパルス加熱に対する裏 面温度の過渡応答式が導かれている. また文献[14]では半 透明体内の温度勾配を一定とする近似の元に半透明体の 一端を定常加熱する場合の光学厚さ全領域に対する定常 熱伝導率の近次式を導いている.

筆者は前報[13]において, 光学厚さ全領域の熱伝導と熱 放射が共存する半透明体の過渡応答式を導出した. 本論文 ではこの式を用いて熱伝導と熱放射が共存する半透明体 の定常熱移動現象を検討することとする. 本論文では以下 の項目を取り上げる. 
(1) 文献 [13]に導出された過渡応答温度式より半透明体 の定常試料温度式を導き, 半透明体内温度分布等を検 討する.

(2) 定常温度式より放射の効果を含む見かけの熱伝導率 式を導き，見かけの熱伝導率の吸収係数（光学厚さ） および温度依存性を検討する。

(3) 定常状態における見かけの熱伝導率の近似式を，( i ) 光学厚さが大きく材料内の放射による伝熱が熱伝導 と同様に材料内の温度勾配に比例して生じる熱伝導 的熱移動領域および (ii) 光学厚さが小さく放射によ る熱移動が伝導による熱移動とは異なった形態で生 じるような熱放射的熱移動領域でそれぞれ導く.

(4) 本研究で得られる見かけの熱伝導率式について熱伝 導的熱移動領域におけるロスランドの見かけの熱伝 導率近似式 $[3]$ およ゙文献 $[14]$ で導いた半透明体の簡 便な定常熱伝導率近似式と比較検討する.

\section{2. 熱伝導モデルと試料温度}

両端を不透明材料で挟まれた半透明体（図 1) を検討対 象とし, この試料の一方の端面 $(x=0)$ より定常熱流束で加 熱する場合を想定する.

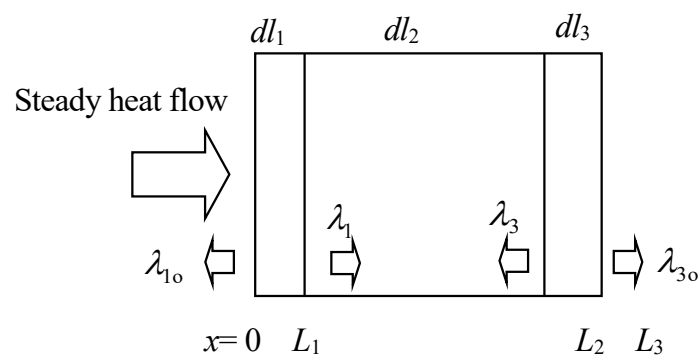

Fig.1 Thermal conduction model

加熱高温側から裏面低温側に定常熱流束が流れるが, 両端 の不透明体内では熱伝導による熱流束, 第 2 層半透明体内 では熱伝導と熱放射による熱流束により熱エネルギーが 移動する. このような 3 層材料の第 2 層半透明体内熱伝導 を検討することとする. この際, 加熱前の定常温度を $T_{0}$ とし，この定常温度から変化する温度を $T\left(T<<T_{0}\right)$ として 評価することとする. 第 2 層半透明体の熱伝導現象を検討 するに当たり次の 5 つを仮定する.

(1) 無限平板を仮定し, 熱伝導, 熱放射とも一次元熱伝導
とする.

(2) 半透明体の吸収係数 $\mu$, 屈折率 $n$ および半透明体に接 寸る不透明体の放射率 $\varepsilon$ は温度, 波長に依存しない. これらの值の波長に対する重み付けをした平均值を 用いた検討が多くなされており [2]，本論文でもこれ らの物性值に対し波長に対する平均值が適用できる ものとして展開する.

(3) 媒体内には粒子、繊維等の不均質な部分が存在せず赤 外線の散乱はない。

(4) 層間に熱抵抗は存在しない.

(5) 放射を生じる不透明体面はランバート余弦法則が成 立する面とする.

文献[13]で 3 層材第 2 層が半透明体, 第 1 層, 第 3 層が 不透明体の試料裏面温度過渡応答式を上記と同じ仮定の 下に導いた. 第 2 層半透明体の過渡応答式を同様の手順で 導き試料表面を定常加熱する場合の第 2 層試料温度式を 導 $<$.

定常状態における試料温度式は，次の手順により導く。 (1)入熱を定常加熱とすると,ラプラス空間における加熱熱 流束はラプラス変数を $p$ としてステップ関数に対する次 式で表される.

$Q f(p)=\frac{Q}{p}$

(2)試料表裏面の放射損失は，加熱側は無し $\left(\lambda_{I_{0}}=0\right)$ ，裏 面側は有りとし, 加熱熱流束は裏面側から放射により失 われる。

(3)時刻œにおける温度定常値は次式を用いて求める.

$$
T(x, t \rightarrow \infty)=\lim _{p \rightarrow 0} T(x, p) p
$$

文献 $[13]$ で導いた半透明体裏面温度の過渡応答式と同様 の仮定・手順により第 2 層半透明体の熱伝導的あるいは熱 放射的熱移動領域における過渡温度式を導き，Eq. (2.3) を得る.ここに第 $\mathrm{i}$ 層の密度, 比熱容量, 熱拡散率, 熱伝 導率，厚さを $\rho_{i}, C_{i}, \alpha_{i}, k_{i}, d l_{i}$, 第 1 層および第 3 層不 透明体の放射率を $\varepsilon_{1}, \varepsilon_{3}$, 第 2 層半透明体の吸収係数, 屈 折率を $\mu, n$ とする. 加熱面 $(x=0)$ から $\mathrm{i}$ 層と $\mathrm{i}+1$ 層の界 面までの厚さを $L_{i}$ とする．また $\lambda_{1}, \lambda_{3}$ は第 1 層および第 
3 層から第 2 層半透明体に放射される放射熱流束の放射 定数， $\lambda_{10} ， \lambda_{30}$ は第 1 層および第 3 層から外部に放射され る放射熱流束の放射定数， $\lambda_{2}$ は第 2 層半透明体内におい て単位体積, 単位時間あたり放射される放射熱流束の放射 定数を表す. $\mu_{\mathrm{c}}$ は熱伝導的熱移動領域と熱放射的熱移動領 域の境界を表す吸収係数であり，この境界を与える光学厚 さより導かれる[14].

$$
\begin{aligned}
& T_{2}(x, p, \beta)
\end{aligned}
$$

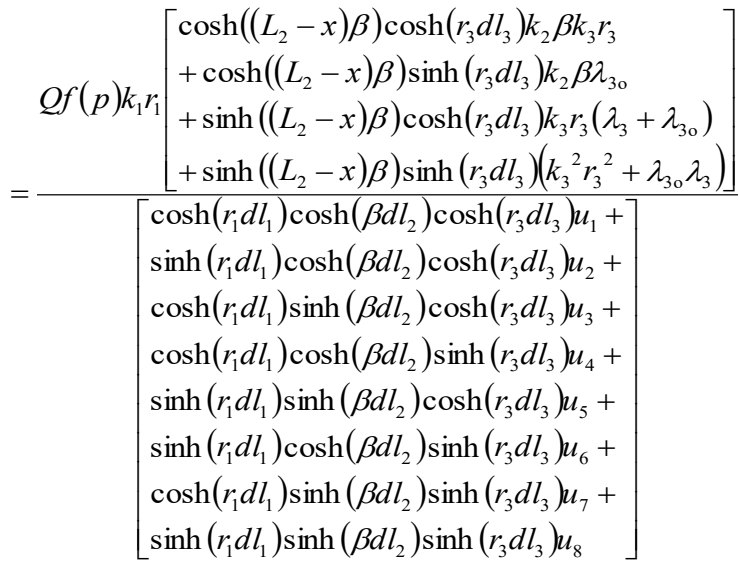

この式の $u_{1} \sim u_{8}$ は Eq. (2.3-1)〜Eq. (2.3-8) で表され, $\lambda_{1}$, $\lambda_{3}, \lambda_{1 \mathrm{o}}, \lambda_{3 \mathrm{o}}, \lambda_{2}, \beta_{1}, \beta_{3}, r_{i}, \mu_{\mathrm{c}}, p_{\mathrm{c}}$ は Eq. (2.4) $\sim$ Eq. (2. 13) で表される. ここに $\sigma$ はステファン・ボルツマン定数で ある. Eq. (2.3)の $\beta$ に $\beta_{1}$ を代入することにより熱放射的 熱移動領域の温度式を, $\beta_{3}$ を代入することにより熱伝導 的熱移動領域の温度式を得る.

$$
\begin{aligned}
& u_{1}=k_{1} r_{1} k_{2} \beta k_{3} r_{3}\left(\lambda_{1}+\lambda_{\mathrm{lo}}+\lambda_{3}+\lambda_{3 \mathrm{o}}\right) \\
& u_{2}=k_{2} \beta k_{3} r_{3}\left(k_{1}^{2} r_{1}^{2}+\lambda_{10} \lambda_{1}+\lambda_{1 \mathrm{o}}\left(\lambda_{3}+\lambda_{3 \mathrm{o}}\right)\right) \\
& u_{3}=k_{1} r_{1} k_{3} r_{3}\left(k_{2}^{2} \beta^{2}+\left(\lambda_{1}+\lambda_{\text {lo }}\right)\left(\lambda_{3}+\lambda_{3 o}\right)\right) \\
& u_{4}=k_{1} r_{1} k_{2} \beta\left(k_{3}{ }^{2} r_{3}{ }^{2}+\lambda_{30} \lambda_{3}+\left(\lambda_{1}+\lambda_{10}\right) \lambda_{3 \mathrm{o}}\right) \\
& u_{5}=k_{3} r_{3}\left(k_{1}^{2} r_{1}^{2}\left(\lambda_{3}+\lambda_{30}\right)+k_{2}^{2} \beta^{2} \lambda_{10}+\lambda_{10} \lambda_{1}\left(\lambda_{3}+\lambda_{30}\right)\right) \\
& u_{6}=k_{2} \beta\left(k_{1}^{2} r_{1}^{2} \lambda_{30}+k_{3}^{2} r_{3}^{2} \lambda_{10}+\lambda_{10} \lambda_{30}\left(\lambda_{1}+\lambda_{3}\right)\right)
\end{aligned}
$$

$$
\begin{aligned}
u_{7}= & k_{1} r_{1}\left(k_{2}{ }^{2} \beta^{2} \lambda_{30}+k_{3}{ }^{2} r_{3}{ }^{2}\left(\lambda_{1}+\lambda_{\mathrm{lo}}\right)+\left(\lambda_{1}+\lambda_{\mathrm{lo}}\right) \lambda_{30} \lambda_{3}\right) \\
u_{8}= & k_{1}{ }^{2} r_{1}{ }^{2} k_{3}{ }^{2} r_{3}{ }^{2}+k_{1}{ }^{2} r_{1}^{2} \lambda_{30} \lambda_{3}+k_{2}{ }^{2} \beta^{2} \lambda_{10} \lambda_{30} \\
& +k_{3}{ }^{2} r_{3}{ }^{2} \lambda_{10} \lambda_{1}+\lambda_{10} \lambda_{1} \lambda_{30} \lambda_{3}
\end{aligned}
$$

$\lambda_{1}=4 \varepsilon_{1} n^{2} \sigma T_{0}^{3}$

$\lambda_{3}=4 \varepsilon_{3} n^{2} \sigma T_{0}^{3}$

$$
\lambda_{\mathrm{lo}}=4 \varepsilon_{1} \sigma T_{0}^{3}
$$

$\lambda_{30}=4 \varepsilon_{3} \sigma T_{0}^{3}$

$\lambda_{2}=4 n^{2} \sigma T_{0}^{3}$

$\beta_{1}=\sqrt{\frac{\left(p+\frac{2 \mu \lambda_{2}}{\rho_{2} C_{2}}+\alpha_{2} \mu^{2}\right)+\sqrt{\left(p+\frac{2 \mu \lambda_{2}}{\rho_{2} C_{2}}+\alpha_{2} \mu^{2}\right)^{2}-4 \alpha_{2} \mu^{2} p}}{2 \alpha_{2}}}$

$\beta_{3}=\sqrt{\frac{\left(p+\frac{2 \mu \lambda_{2}}{\rho_{2} C_{2}}+\alpha_{2} \mu^{2}\right)-\sqrt{\left(p+\frac{2 \mu \lambda_{2}}{\rho_{2} C_{2}}+\alpha_{2} \mu^{2}\right)^{2}-4 \alpha_{2} \mu^{2} p}}{2 \alpha_{2}}}$

$$
r_{i}=\sqrt{p / \alpha_{i}} \quad i=1,3
$$

$\mu_{\mathrm{c}} d l_{2}=1.79$

$$
p_{\mathrm{c}}=\alpha_{2} \mu_{\mathrm{c}}^{2}
$$

この第 2 層過渡応答試料温度式を用いて熱伝導および熱 放射が共存する光学厚さ全領域における第 2 層試料温度 式として Eq. (2.14)を得る[13].

$$
\begin{aligned}
T_{2}(x, p)= & \left\{\frac{\mu_{\mathrm{c}}-\mu}{2\left(\beta_{1}\left(p_{\mathrm{c}}\right)-\beta_{3}\left(p_{\mathrm{c}}\right)\right)}+\frac{1}{2}\right\} T_{2}\left(x, p, \beta_{1}(p)\right) \\
& +\left\{-\frac{\mu_{\mathrm{c}}-\mu}{2\left(\beta_{1}\left(p_{\mathrm{c}}\right)-\beta_{3}\left(p_{\mathrm{c}}\right)\right)}+\frac{1}{2}\right\} T_{2}\left(x, p, \beta_{3}(p)\right)
\end{aligned}
$$

第 2 層温度 Eq. (2.3)において第 1 層及び第 3 層厚さを 
$d l_{1}=d l_{3}=0$ とすることにより, 表裏面を不透明にした単層 半透明体の熱放射的熱移動あるいは熱伝導的熱移動にお ける過渡応答温度 Eq. (2.15) を得る. 表裏面を不透明化し た半透明体単層の光学厚さ全領域における試料裏面温度 は，Eq. (2. 15)を Eq. (2.14)に代入することにより与えら れる.

$T_{2}(x, p, \beta)$

$=\frac{Q f(p)\left[\cosh \left(\left(L_{2}-x\right) \beta\right) k_{2} \beta+\sinh \left(\left(L_{2}-x\right) \beta\right)\left(\lambda_{3}+\lambda_{30}\right)\right]}{\left[\cosh \left(\beta d l_{2}\right)\right)\left(k_{2} \beta\left(\lambda_{1}+\lambda_{10}+\lambda_{3}+\lambda_{30}\right)+\right]}$ $\left[\begin{array}{l}\cosh \left(\beta d l_{2}\right)\left\{k_{2} \beta\left(\lambda_{1}+\lambda_{10}+\lambda_{3}+\lambda_{30}\right)\right\}+ \\ \sinh \left(\beta d l_{2}\right)\left\{k_{2}^{2} \beta^{2}+\left(\lambda_{1}+\lambda_{10}\right)\left(\lambda_{3}+\lambda_{30}\right)\right\}\end{array}\right]$

光学厚さ全領域の第 2 層試料温度式Eq. (2.14)を用いて 第 2 層の定常温度式を本項に記載した方法で求める. 熱伝 導的熱移動領域と熱放射的熱移動領域の第 2 層定常温度 式およびその和である光学厚さ全領域の第 2 層定常温度 式を以下に示す.

（1）熱伝導的熱移動領域の第 2 層半透明体定常温度

Eq. (2.3) およびEq. (2.14) 右辺第 2 項を用いて熱伝導的 熱移動領域における定常第 2 層温度式Eq. (2.16)が得られ る.この際, Eq. (2. 10)の $\beta_{3}$ は $p=0(t \rightarrow \infty$ に対応 $)$ において 0 となる.

$T_{2 \text { dif }}(x, t \rightarrow \infty)$

$=\left\{-\frac{\mu_{\mathrm{c}}-\mu}{2\left(\beta_{1}\left(p_{\mathrm{c}}\right)-\beta_{3}\left(p_{\mathrm{c}}\right)\right)}+\frac{1}{2}\right\} \frac{Q\left[\begin{array}{l}k_{2} k_{3}+k_{2} d l_{3} \lambda_{30} \\ +\left(L_{2}-x\right)\left\{k_{3}\left(\lambda_{3}+\lambda_{30}\right)+d l_{3} \lambda_{30} \lambda_{3}\right\}\end{array}\right]}{\left[\begin{array}{l}k_{2} k_{3}\left(\lambda_{1}+\lambda_{3}+\lambda_{30}\right)+k_{3} d l_{2} \lambda_{1}\left(\lambda_{3}+\lambda_{30}\right) \\ +k_{2} d l_{3} \lambda_{30}\left(\lambda_{1}+\lambda_{3}\right)+d l_{2} d l_{3} \lambda_{1} \lambda_{3} \lambda_{30}\end{array}\right]}$

（2）熱放射的熱移動領域の第 2 層半透明体定常温度

Eq. (2.3)およびEq. (2.14)右辺第 1 項を用いて熱放射的 熱移動領域における定常第 2 層温度 Eq. (2.18) を得る. ここに Eq. (2.9)の $\beta_{1}$ は $p=0(t \rightarrow \infty$ に対応 $)$ におい Eq. (2.17) となり, 熱伝導的熱移動領域の $\beta_{3}$ と異なり有限 の值を示す.

$\beta_{10}=\sqrt{\frac{\left(\frac{2 \mu \lambda_{2}}{\rho_{2} C_{2}}+\alpha_{2} \mu^{2}\right)}{\alpha_{2}}}$

$$
\begin{aligned}
& T_{2 \text { rad }}(x, t \rightarrow \infty)
\end{aligned}
$$

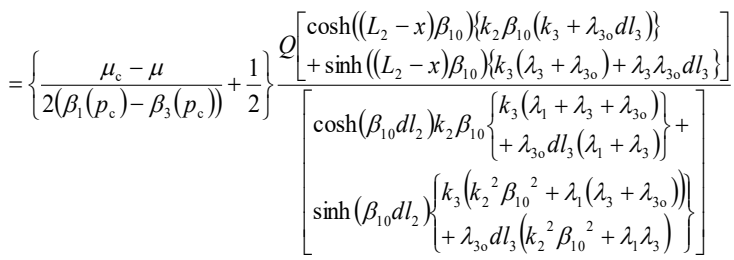

(3) 光学厚さ全領域の第 2 層半透明体温度

これより 3 層材第 2 層の定常温度式として Eq. (2.16)お よびEq. (2.18)より次式を得る.

$$
\begin{aligned}
& T_{2}(x, t \rightarrow \infty)=T_{2 \text { rad }}(x, t \rightarrow \infty)+T_{2 \text { dif }}(x, t \rightarrow \infty)
\end{aligned}
$$

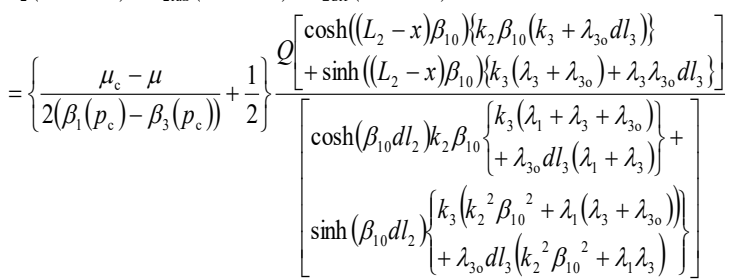

$$
\begin{aligned}
& +\left\{-\frac{\mu_{\mathrm{c}}-\mu}{2\left(\beta_{1}\left(p_{\mathrm{c}}\right)-\beta_{3}\left(p_{\mathrm{c}}\right)\right)}+\frac{1}{2}\right\} \frac{Q\left[\begin{array}{l}
k_{2} k_{3}+k_{2} d l_{3} \lambda_{30} \\
+\left(L_{2}-x\right)\left\{k_{3}\left(\lambda_{3}+\lambda_{30}\right)+d l_{3} \lambda_{30} \lambda_{3}\right\}
\end{array}\right]}{\left[\begin{array}{l}
k_{2} k_{3}\left(\lambda_{1}+\lambda_{3}+\lambda_{30}\right)+k_{3} d l_{2} \lambda_{1}\left(\lambda_{3}+\lambda_{30}\right) \\
+k_{2} d l_{3} \lambda_{30}\left(\lambda_{1}+\lambda_{3}\right)+d l_{2} d l_{3} \lambda_{1} \lambda_{3} \lambda_{30}
\end{array}\right]}
\end{aligned}
$$

上式により第 1 層/第 3 層が不透明体、第 2 層が半透明 体の 3 層材料の第 2 層内温度分布を表 1 に示す物性值を仮 定して求め図 2〜図 3 に示す. この際, 加熱熱流束 $Q=1\left(\mathrm{~W} / \mathrm{m}^{2}\right)$ とした.

Table1 Input data of thermal properties

\begin{tabular}{|l|r|r|r|}
\hline & \multicolumn{1}{|c|}{$1^{\text {st }}$ layer } & $2^{\text {nd }}$ layer & $3^{\text {rd }}$ layer \\
\hline$\rho\left(\mathrm{kg} / \mathrm{m}^{3}\right)$ & $1.0 \times 10^{3}$ & $1.0 \times 10^{3}$ & $1.0 \times 10^{3}$ \\
\hline$C(\mathrm{~J} / \mathrm{kg} / \mathrm{K})$ & $1.0 \times 10^{3}$ & $1.0 \times 10^{3}$ & $1.0 \times 10^{3}$ \\
\hline$\alpha\left(\mathrm{m}^{2} / \mathrm{s}\right)$ & $1.0 \times 10^{-5}$ & $1.0 \times 10^{-5}$ & $1.0 \times 10^{-5}$ \\
\hline$d l(\mathrm{~m})$ & $5.0 \times 10^{-4}$ & $5.0 \times 10^{-2}$ & $5.0 \times 10^{-4}$ \\
\hline$\varepsilon_{1}, \varepsilon_{3}$ & 0.5 & & \\
\hline$n^{2}$ & & & \\
\hline$\mu(1 / \mathrm{m})$ & & $10 \sim 500$ & \\
\hline
\end{tabular}


第 2 層試料厚さ $50 \mathrm{~mm}$ の場合，熱放射的熱移動と熱伝導 的熱移動の境界を与える吸収係数は Eq. (2.12)より $\mu_{\mathrm{c}}=35.9(1 / \mathrm{m})$ となる.これらの図において横軸の $x$ は第 1 層と第 2 層の境界からの距離とし, 縦軸を表す温度は第 2 層温度から第 2 層と第 3 層の境界温度を引いた值とした。 またこれらの図には，第 2 層がほぼ熱伝導と考えられる $T_{0}=300 \mathrm{~K}, \mu=10000(1 / \mathrm{m})$ の温度分布も記載した. 吸収係数 $\mu$ が増大するに従い両端温度差の温度勾配絶対值が一旦小 さくなり，その後温度勾配絶対值が大きくなる.これは吸 収係数の増大に伴い見かけの熱伝導率が一旦大きくなり, 更に吸収係数が大きくなると見かけの熱伝導率が減少す ることを示している.

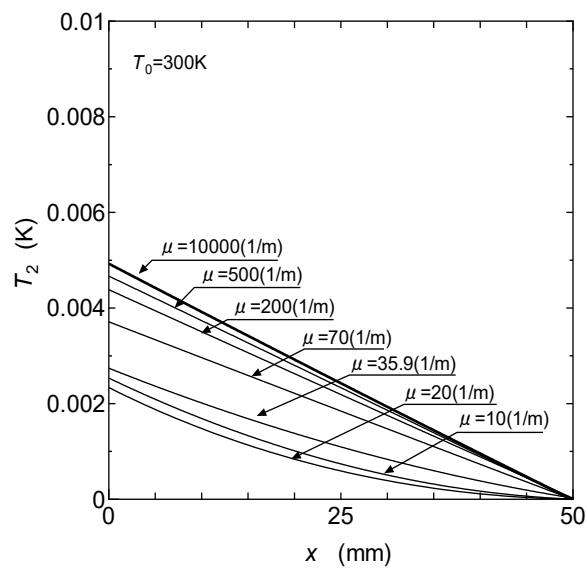

Fig. $22^{\text {nd }}$ layer temperature $\left(T_{0}=300 \mathrm{~K}\right)$

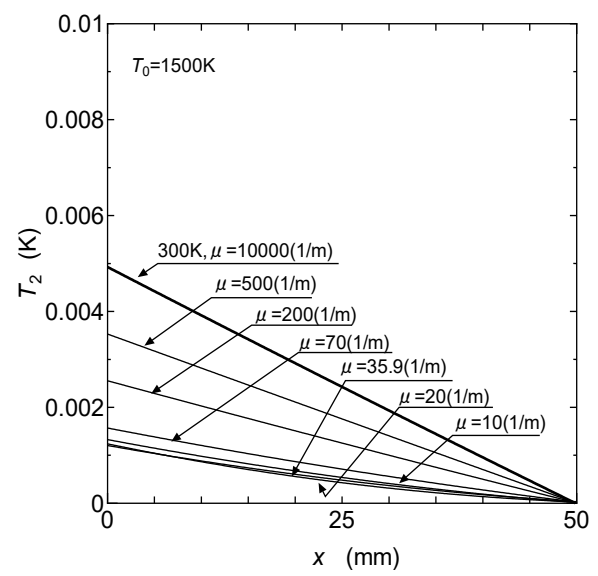

Fig. $32^{\text {nd }}$ layer temperature $\left(T_{0}=1500 \mathrm{~K}\right)$

\section{3．見かけの熱伝導率}

第 2 層の見かけの熱伝導率 $k_{2}$ 一として定常状態におけ る $x=L_{1}$ および $x=L_{2}$ の温度差を用いて次式により定義し, 半透明体の見かけの熱伝導率 $k_{2}$ `を導く.

$T_{2}\left(L_{1}, t \rightarrow \infty\right)-T_{2}\left(L_{2}, t \rightarrow \infty\right)=\frac{Q d l_{2}}{k_{2}{ }^{\prime}}$

（1）光学厚さ全領域における見かけの熱伝導率

半透明体である第 2 層両端温度差は, 熱放射的熱移動領 域の第 2 層試料温度式 Eq. (2.18) より得られる第 2 層両端 温度差 $\Delta T_{2 \mathrm{rad}}$ および熱伝導的熱移動領域の第 2 層試料温 度式Eq. (2.16) より得られる第 2 層両端温度差 $\Delta T_{2 \mathrm{dif}}$ を加 えることにより得られる.これより光学厚さ全領域におけ る見かけの熱伝導率として次式を得る.

$k_{2}{ }^{\prime}=\frac{Q\left(L_{2}-L_{1}\right)}{\triangle T_{2 \mathrm{rad}}+\triangle T_{2 \mathrm{dif}}}$

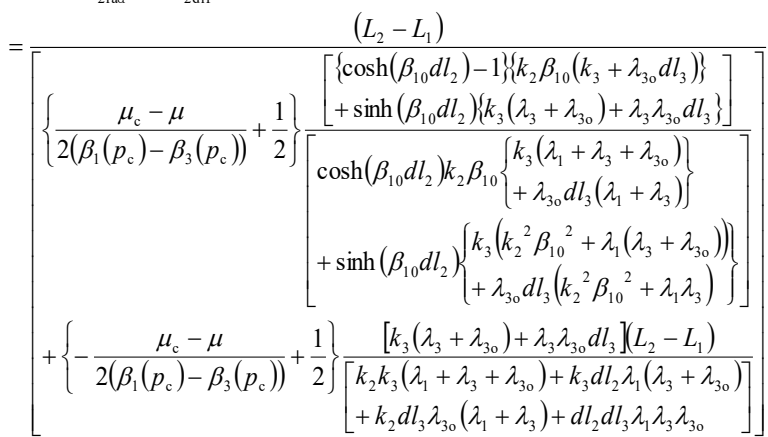

（2）熱伝導的熱移動領域における見かけの熱伝導率 吸収係数が $\mu>>\mu_{\mathrm{c}}$ となる熱伝導的熱移動領域における 見かけの熱伝導率は, 次式となる.

$$
\begin{aligned}
k_{2}{ }^{\prime}= & \frac{Q\left(L_{2}-L_{1}\right)}{\triangle T_{2 \mathrm{dif}}} \\
& =\frac{\left[\begin{array}{l}
k_{2} k_{3}\left(\lambda_{1}+\lambda_{3}+\lambda_{30}\right)+k_{3} d l_{2} \lambda_{1}\left(\lambda_{3}+\lambda_{30}\right) \\
+k_{2} d l_{3} \lambda_{30}\left(\lambda_{1}+\lambda_{3}\right)+d l_{2} d l_{3} \lambda_{1} \lambda_{3} \lambda_{30}
\end{array}\right]}{\left\{-\frac{\mu_{\mathrm{c}}-\mu}{2\left(\beta_{1}\left(p_{\mathrm{c}}\right)-\beta_{3}\left(p_{\mathrm{c}}\right)\right)}+\frac{1}{2}\right\}\left[k_{3}\left(\lambda_{3}+\lambda_{30}\right)+d l_{3} \lambda_{30} \lambda_{3}\right]}
\end{aligned}
$$

吸収係数が大きく Eq. (3.4)の近似が成立する時, 熱伝導 
的熱移動領域における見かけの熱伝導率の近似式は Eq. (3.5) で与えられる. この際、第 3 層厚さ $\left(d l_{3}\right)$ を 0 と した.

$1>\frac{\lambda_{2}}{k_{2} \mu}, \frac{\mu_{\mathrm{c}}}{\mu}$

$k_{2}^{\prime} \approx k_{2}\left(1+\frac{\lambda_{2}}{2 k_{2} \mu}\right)\left(1+\frac{\lambda_{1}}{\left(\lambda_{3}+\lambda_{30}\right)}+\frac{\lambda_{1} d l_{2}}{k_{2}}\right)$

同式に Eq. (2.4)〜Eq. (2.8)に与える $\lambda_{1} ， \lambda_{3} ， \lambda_{30} ， \lambda_{2}$ を代 入し, Eq. (3.6) を得る.Eq. (3.6)の右辺の第 1 括弧は,

Eq. (3.7)に与えるロスランドの近似式に近い関係式とな っており，半透明体内の吸収・放射現象による見かけの熱 伝導率を表している. 熱伝導的熱移動領域においては吸収 係数が小さくなるに従い見かけの熱伝導率が大きくなる.

$k_{2}{ }^{\prime} \approx k_{2}\left(1+\frac{2 n^{2} \sigma T_{0}^{3}}{k_{2} \mu}\right)\left(\begin{array}{c}1+\frac{\varepsilon_{1} n^{2}}{\varepsilon_{3}\left(1+n^{2}\right)} \\ +\frac{4 \varepsilon_{1} n^{2} \sigma T_{0}{ }^{3} d l_{2}}{k_{2}}\end{array}\right)$

$$
k^{\prime}=k\left(1+\frac{16 n^{2} \sigma T^{3}}{3 k \mu}\right)
$$

Eq. (3. 5) および Eq. (3.6)の右辺第 2 括弧は, 半透明体 端面の放射現象に依存した見かけの熱伝導率を表してい る.Eq. (3.5) およびEq. (3.6)の右辺第 2 括弧最後の項は, 文献 [14]の半透明体内定常温度勾配を定数近似して求め た端面間の直接的な放射熱流束の授受に対する見かけの 熱伝導率近似式 Eq. (3.8) と比較すると, 多重反射に伴う 光学厚さ依存性を除いて一致している.これよりこの項が 端面間の直接的な放射熱流束の授受を表しているものと 考えられる.

$$
k_{\mathrm{S}} \approx 4 \varepsilon n^{2} \sigma T_{0}^{3} l \frac{\exp (-\mu l)}{1+(1-\varepsilon) \exp (-\mu l)}
$$

Eq. (3. 5)の右辺第 2 括弧の第 2 項は, 加熱面側の放射定 数 $\left(\lambda_{1}\right)$ の裏面側放射定数の和 $\left(\lambda_{3}+\lambda_{30}\right)$ に対する比とな っており，この值が大きいほど多重反射の過程で半透明体 を通過する積算放射熱流束が大きいことを表していると 考えられ，この過程で第 1 括弧に示す半透明体内の吸収・ 放射現象に伴う見かけの熱伝導率が大きくなるのではな
いかと考えられる。

（3）熱放射的熱移動領域における見かけの熱伝導率 吸収係数が $\mu<\mu_{\mathrm{c}}$ となる熱放射的熱移動領域における見 かけの熱伝導率として Eq. (3.9)を得る.この式に対し $\mu$ $<\mu_{\mathrm{c}}$ の関係を用いたマクローリン展開により，熱放射的 熱移動領域の見かけの熱伝導率の近似式 Eq. (3.10) が得 られる.この際、第 3 層厚さ $\left(d l_{3}\right)$ を 0 とした.

$k_{2}^{\prime}=\frac{Q\left(L_{2}-L_{1}\right)}{\triangle T_{2}}$

$=\frac{\left[\begin{array}{l}\cosh \left(\beta_{10} d l_{2}\right) k_{2} \beta_{10}\left\{\begin{array}{l}k_{3}\left(\lambda_{1}+\lambda_{3}+\lambda_{30}\right) \\ +\lambda_{30} d l_{3}\left(\lambda_{1}+\lambda_{3}\right)\end{array}\right\} \\ +\sinh \left(\beta_{10} d l_{2}\right)\left\{\begin{array}{l}k_{3}\left(k_{2}^{2} \beta_{10}{ }^{2}+\lambda_{1}\left(\lambda_{3}+\lambda_{30}\right)\right) \\ +\lambda_{30} d l_{3}\left(k_{2}^{2} \beta_{10}{ }^{2}+\lambda_{1} \lambda_{3}\right)\end{array}\right\}\end{array}\right]\left(L_{2}-L_{1}\right)}{\left\{\frac{\mu_{\mathrm{c}}-\mu}{2\left(\beta_{1}\left(p_{\mathrm{c}}\right)-\beta_{3}\left(p_{\mathrm{c}}\right)\right)}+\frac{1}{2}\right\}\left[\begin{array}{l}\left\{\cosh \left(\beta_{10} d l_{2}\right)-1\right\}\left\{k_{2} \beta_{10}\left(k_{3}+\lambda_{30} d l_{3}\right)\right\} \\ +\sinh \left(\beta_{10} d l_{2}\right)\left\{k_{3}\left(\lambda_{3}+\lambda_{30}\right)+\lambda_{3} \lambda_{30} d l_{3}\right\}\end{array}\right]}$

$$
k_{2}^{\prime} \approx k_{2}\left(1+\frac{1}{2} \frac{\lambda_{2} \mu}{k_{2} \mu_{\mathrm{c}}^{2}}\right)\left(1+\frac{\lambda_{1}}{\left(\lambda_{3}+\lambda_{30}\right)}+\frac{\lambda_{1} d l_{2}}{k_{2}}\right)
$$

同式に Eq. (2.4)〜Eq. (2. 8), Eq. (2.12)に与える $\lambda_{1}, \lambda_{3}$, $\lambda_{3 \mathrm{o}}, \lambda_{2}, \mu_{\mathrm{c}}$ を代入し, Eq. (3.11) を得る.

$$
k_{2}{ }^{\prime} \approx k_{2}\left(1+\frac{2 n^{2} \sigma T_{0}^{3} \mu d l_{2}^{2}}{(1.79)^{2} k_{2}}\right)\left(\begin{array}{c}
1+\frac{\varepsilon_{1} n^{2}}{\varepsilon_{3}\left(1+n^{2}\right)} \\
+\frac{4 \varepsilon_{1} n^{2} \sigma T_{0}^{3} d l_{2}}{k_{2}}
\end{array}\right)
$$

Eq. (3.10)および Eq. (3.11)右辺の第 1 括弧は, 吸収係 数が大きくなるに従い, 見かけの熱伝導率が大きくなる現 象を表している．この結果は，我々が文献[14]において定 常状態における半透明体内の温度勾配を定数に近似して 求めた熱放射的熱移動領域における半透明体内の吸収・放 射現象による見かけの熱伝導率式 Eq. (3.12) と係数を除 いて同じである。

$$
k_{\mathrm{V}} \approx 2 \lambda_{2} \mu l^{2}=8 n^{2} \sigma T_{0}^{3} \mu l^{2}
$$

これより Eq. (3.10)およびEq. (3.11)右辺の第 1 括弧の第 2 項が，半透明体内における吸収・放射現象による見かけ の熱伝導率を表していると考えられる.

Eq. (3.10) および Eq. (3.11)右辺の第 2 括弧は，見かけ の熱伝導率の半透明体端面の放射現象依存性を表してお 
り, 熱伝導的熱移動領域の見かけの熱伝導率近似式 Eq. (3.6)右辺の第 2 括弧の項と同じである.

この結果は $\mu \rightarrow 0$ において熱放射的熱移動領域における 見かけの熱伝導率 $k_{2}{ }^{-}$は，半透明体内の吸収・放射現象 による第 1 括弧の項は 1 となるが, 第 2 括弧の半透明体端 面の放射現象による項が 1 より大きい值となり, 見かけの 熱伝導率 $k_{2}$ `が $k_{2}$ より大きい值に収束することを示して いる.

\section{5 . 結論}

一次元熱伝導条件における半透明体の定常熱伝導を検 討し，次のことを確認した.

(1) 半透明体定常温度式を導き, 同式を用いて見かけの熱 伝導率式を導いた。

(2) 定常状態における見かけの熱伝導率の近似式は, 熱伝 導的熱移動領域, 熱放射的熱移動領域とも半透明体内 の吸収・放射現象によるものと端面放射現象によるも のの積となる.それぞれの見かけの熱伝導率増分の伝 導熱伝導率 $k_{2}$ に対する比が 1 より小さい時, 見かけ の熱伝導率の増分は両者の和に近似され、文献 [13] と同様の式となる.

(3) 熱伝導的熱移動領域における吸収・放射現象による見 かけの熱伝導率式は, 定数を除いてロスランドの近似 式と同じ関係式を得た.また熱放射的熱移動領域にお ける吸収・放射現象による見かけの熱伝導率式は、定 数を除いて文献[13]と同じ関係式を得た。

(4) 熱伝導的熱移動領域においては, 吸収係数が小さくな るに従い見かけの熱伝導率 $k_{2}$ ‘ は大きくなる.また， 熱放射的熱移動領域では, 吸収係数が大きくなるに従 い見かけの熱伝導率 $k_{2}$ ‘ は大きくなり, 吸収係数 0 においては半透明体端面間の熱放射により $k_{2}$ より大 きい值に収束することが予想される.

\section{NOMENCLATURE}

$T_{i .}: i^{\text {th }}$ layer temperature, $\mathrm{K}$

$T_{0}$. : steady state temperature, $\mathrm{K}$

$\alpha_{i}: i^{\text {th }}$ layer thermal diffusivity, $\mathrm{m}^{2} / \mathrm{s}$

$C_{i} \quad: i^{\text {th }}$ layer specific heat capacity, $\mathrm{J} / \mathrm{kg} / \mathrm{K}$

$\rho_{i}: i^{\text {th }}$ layer density, $\mathrm{kg} / \mathrm{m}^{3}$

$k_{i} \quad: i^{\text {th }}$ layer thermal conductivity, $\mathrm{W} / \mathrm{m} / \mathrm{K}$

$k_{\mathrm{v}} \quad$ : thermal conductivity by radiation and absorption of semitransparent material, $\mathrm{W} / \mathrm{m} / \mathrm{K}$ $k_{\mathrm{s}} \quad:$ thermal conductivity by heat transfer between semitransparent material's both ends, $\mathrm{W} / \mathrm{m} / \mathrm{K}$

$\mu \quad$ : absorption coefficient, $1 / \mathrm{m}$

$\mu_{\mathrm{c}}$ : boundary absorption coefficient between radiative heat conduction and diffusive heat conduction, $1 / \mathrm{m}$

$n \quad$ : refractive index

$\varepsilon \quad:$ emissivity

$\varepsilon_{i} \quad: i^{\text {th }}$ layer emissivity

$\sigma \quad$ :Stefan-Boltzmann constant $\quad, \mathrm{W} / \mathrm{m}^{2} / \mathrm{K}^{4}$

$Q f(t)$ : heat flux, $\mathrm{W} / \mathrm{m}^{2}$

$\lambda_{10}:$ radiation coefficient of front surface in contact with outside, $\mathrm{W} / \mathrm{m}^{2} / \mathrm{K} \quad \lambda_{1 \mathrm{o}}=4 \varepsilon_{1} \sigma T_{0}^{3}$

$\lambda_{30}:$ radiation coefficient of rear surface in contact with outside, $\mathrm{W} / \mathrm{m}^{2} / \mathrm{K} \quad \lambda_{30}=4 \varepsilon_{3} \sigma T_{0}^{3}$

$\lambda_{1}$ :radiation coefficient of front surface in contact with semitransparent material, $\mathrm{W} / \mathrm{m}^{2} / \mathrm{K} \quad \lambda_{1}=4 \varepsilon_{1} n^{2} \sigma T_{0}^{3}$

$\lambda_{3}$ : radiation coefficient of rear surface in contact with semitransparent material, $\mathrm{W} / \mathrm{m}^{2} / \mathrm{K} \quad \lambda_{3}=4 \varepsilon_{3} n^{2} \sigma T_{0}^{3}$

$\lambda_{2}$ : radiation coefficient of semitransparent material, $\mathrm{W} / \mathrm{m}^{2} / \mathrm{K} \quad \lambda_{2}=4 n^{2} \sigma T_{0}^{3}$

$l \quad:$ thickness, $\mathrm{m}$

$d l_{i} \quad: i^{\text {th }}$ layer thickness, $\mathrm{m}$

$L_{i} \quad$ :thickness $\left(=\sum d l_{j} \quad j=1 \sim i\right), \mathrm{m}$

$x \quad$ :coordinate, $\mathrm{m}$

$t \quad$ :time, $\mathrm{s}$

$p \quad$ :laplace variable, $1 / \mathrm{s}$

$r_{i}: \sqrt{p / \alpha_{i}}, 1 / \mathrm{m}$

\section{参考文献}

[1] N. Araki;"Effect of Radiation Heat Transfer on Thermal Diffusivity Measurements”, Int.J.Thermophys., 11 (1990), 329-337.

[2] H. Ohta,M.Masuda,K.Watanabe,K.Nakajima,H.Shibata, Y.Waseda; 「熱放射の寄与を正確に考慮した溶融連続鋳 造パウダーの熱拡散率測定」, 鉄と鋼, 80 (1994) 463-468.

[3] M. Darby;"Analysis of thermal conductivity experiments on glass at high temperatures", High Temp.-High Press., 15 (1983) 629-644.

[4] S.Andre,A. Degiobanni;"A theoretical study of the transient coupled condition and radiation heat transfer in glass: phonic diffusivity measurements by the flash technique", Int.J.Heat Mass Transfer, 38 (1995) 3401-3412.

[5] H. Mehling G.Hautzinger,O.Nilsson,J.Fricke, R.Hofmann, O.Hahn;’'Thermal Diffusivity of Semitransparent Materials Determined by the laser-Flash Method Applying a New Analytical Model”, Int.J.Thermophys., 19 (1998) 941-949. 
[6] K. Hosono;'Thermal Conduction of Semitransparent Material", 33 ${ }^{\text {rd }}$ Jpn.Symp. Thermophys.Prop., (2012) 140-142.

[7] K. Hosono;'Thermal Conduction of Semitransparent Material”, 34 $4^{\text {th }} J$ pn.Symp. Thermophys.Prop., (2013) 54-56.

[8] K. Hosono;'"Thermal Conduction of Semitransparent Material", 35 ${ }^{\text {th }}$ Jpn.Symp. Thermophys.Prop., (2014) 22-24.

[9] K.Hosono,T,Nishi,H.Ohta;’'Thermal Diffusivity Measurement Method of Transparent Material sandwiched between opaque plates by Flash Method", Netsu Bussei, 32 (2018) 80-87.

[10] S.C.Lee,G.R.Cunnington;"Conduction and Radiation Heat Transfer in High-Porisity Fiber Thermal Insulation”, J.Thermophysics and Heat Transfer, 14,2 (2000) 121-136.

[11] R.Caps,U.Heinemann,J.Fricke,K.Keller;’'Thermal conductivity of polyimide foams", Int.J.Heat Mass
Transfer, 40,2 (1977) 269-280.

[12] T.Ohmura,M.Onodera,M.Naito;'Estimation Method for Attenuation Coefficient of Thermal Radiation in Thermal Insulators by Using Thermal Conductivity", Jpn.J.Appl.Phys., 50(2011) 11RE03.

[13] K.Hosono,T,Nishi,H.Ohta;'Effect of Thermal Radiation on Thermal Diffusivity Measurement of Semitransparent Material with Opaque Layer at Both Ends by Flash Method", Netsu Bussei, 33 (2019) 67-77.

[14] K.Hosono,T,Nishi,H.Ohta;”An Approach to the Simple Calculation Method of Steady Thermal Conductivity of Semitransparent Material”, Netsu Bussei, 32 (2018) 151-156.

[Received May 26, 2019, Accepted Aug. 3, 2019] 